\title{
Utopian Visions for Buenos Aires Shantytowns: Collective Imaginaries of Housing Rights, Upgrading and Eviction (1956- 2013)
}

\author{
ADRIANA LAURA MASSIDDA
}

University of Cambridge

This article explores three utopian visions which have shaped past and present experiences within Buenos Aires shantytowns: those of upgraded shantytowns, of universal housing, and of a city where shantytowns have been eliminated. The article argues that these visions are collective conceptions that entail a socio-political critique which is translated into space and which points to an ideal future. The visions proposed emerge from the examination of historical evidence and are a key conceptual tool for understanding previous and current discussions of shantytowns in Latin America.

Keywords: upgrade, eradication, social housing, Buenos Aires

\section{Bulletin of Latin American Studies}

Special issue edited by Sandra Brunnegger and Jason Pribilsky

Accepted $5^{\text {th }}$ July 2016. Expected 2017.

Accepted version. 
It is in the desire to shape society into a specific form, distributing and arranging it spatially, [...] that utopia emerges. (Heffes, 2013: 21)

This article explores three utopian visions related to Buenos Aires shantytowns which have shaped past and present experiences and urban policies. The first of these visions is that of a city where shantytowns have been upgraded to the point of becoming fully-serviced neighbourhoods. This requires multiple improvements: the provision of piped water, sewage, drainage, electricity, gas and telephone lines; land filling, street paving and lighting; garbage collection; and the installation of facilities such as schools, health centres or nurseries. This idea had some antecedents in the 1950s but only became central to the imagination of shantytown residents and professionals in the mid-1960s. While this vision mainly stems from the imaginations of shantytown dwellers, it occasionally serves as the basis for top-down, and utopic, urban policies.

The second utopian vision is based on the idea that housing is a right of every citizen and imagines that the state can provide universal habitation. In Argentina, this conception emerged gradually between the 1890s and the late 1930s and, in the 1940s, crystallised into the notion of the 'Derecho a la vivienda' ('Right to Housing') promoted by Peronism (Ballent, 2005: 27-64). This conception became fundamental to how poor families envisioned their own housing futures over the rest of the twentieth century, and it remains a guiding vision for architects and planners today. The vision of universal housing differs from that of upgraded shantytowns in that the focus is placed on providing state-built dwelling units for letting or sale rather than upgrading and potentially titling self-built housing on invaded land. However, the two visions are not mutually exclusive and, in fact, they are frequently intertwined.

The final utopian vision examined is that of a city where shantytowns have been forcibly removed and the poor rendered invisible. This negative vision is defined by what it excludes rather than offering a constructive proposal. As this utopian vision seeks to expel marginalised communities from the city, it has the oldest roots in Latin America, since it can be traced back to the Spanish conquest (Hernández, forthcoming).

As intimated, these visions are not mutually exclusive and all three interweave throughout Argentina's recent history. Indeed, they frequently coexist in grassroots and official documents. The idea of state-supported housing, in particular, often appears in the sources accompanying the other two visions. Even the conception of a city stripped of shantytowns, which is, in principle, incompatible with that of upgraded shantytowns, was occasionally proposed together with strategic upgrades. This is the case of the Plan Piloto, as I will discuss later. Thus, while the three utopian visions focused on different 
practical applications (full upgrading, universal housing provision, and forcible removal), they cannot be neatly separated into distinct practices. It is rather that the historical practices examined must be understood as inspired by co-existing visions that overlap within them.

From the moment of its inception, the idea of utopia has been linked to urban space. First coined by Thomas More in his homonymous text, the term 'utopia' simultaneously refers to both the Greek

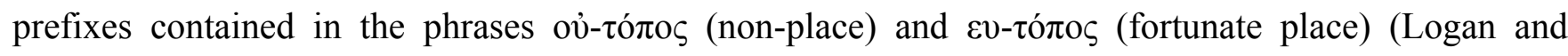
Adams, 2002: xi). Utopia can thus be defined as the formulation of a nonexistent place of perfect happiness, and its spatial character is evident in its very etymology. Moreover, utopias inevitably reveal imperfections in existent worlds and entail a critique of a current state of affairs. Early modern utopias such as More's, for example, denounced specific aspects of the Old World through the creation of imaginary worlds with the qualities that they 'would wish rather than expect to see' in Europe (More, 2002: 107). Utopias, however, are not only descriptive, but also programmatic. They critique a present state of affairs, but also propose an alternative. Thus utopian visions purportedly provide the tools necessary to create the ideal spaces of happiness they describe.

These properties are readily identifiable in the long history of utopian interventions and imagination in the Americas. For example, Spanish conquerors utilised the 'Laws of the Indies' and the 'Ordinances Concerning Discoveries', issued between the sixteenth and the eighteenth centuries, as a tool to impose an ideal, unified, and rigorously planned urban order upon an American space they considered to be empty. Crucially, this utopian vision was perceived to be necessary for civilised inhabitation, and excluded Indigenous people (Salcedo Fidalgo and Zeiderman, 2008: 75-77). This position was replicated after independence by Domingo Faustino Sarmiento through his formulation of the utopian city Argirópolis (1850). Differently, both Francisco de Miranda and Simón Bolívar imagined utopian cities - Colombo (1801) and Las Casas (1815) respectively - which incorporated indigenous people into a new version of the American landscape (Heffes, 2009: 32-77; 2013: 13-14). The twentieth-century correlate of such attempts to organise society through urban distribution is Modernist planning. Examples include Le Corbusier's Plan para Buenos Aires (1938), Cidade dos Motores by Town Planning Associates (1945), and Lúcio Costa's design for Brasilia (1957) (Ballent, 2005: 227-241; Mumford, 1997: 50-58; Lejeune, 2005). Indeed, the Plan Piloto (discussed below) was part of a modern development plan originating with Le Corbusier.

The Colonial disenfranchisement of non-white, indigenous populations demonstrates that different utopias also imply different conceptualisations of citizenship. Modern planning, for example, implicitly posits an egalitarian, universal citizenship, although it proffers no concrete resources to realise this egalitarianism (Holston, 2008: 20, 'differential citizenship'). Similarly, initiatives such as the Plan Piloto were part of the exciting imaginary of a modern city but they made no attempt to articulate how 
to incorporate the entire population within this imagined space. In contrast, land occupation and improvement entailed an insurgency or an attempt by those excluded to simply step in and take those resources necessary for 'de facto citizenship' (Bayat, 2013: 55; Holston, 2008: 6). Indeed, as in the historical examples referenced, I will go on to demonstrate that the utopian visions discussed incorporated spatial, critical and programmatic elements, as they embodied a struggle between different conceptions of citizenship which continues in the present day.

From the historical account above, it can be deduced that utopian visions are collective and entail a socio-political critique of a present state translated into space which points towards an ideal future. Thus, such visions are expressed through a multiplicity of documents. Moreover, in the specific cases studied, not all the groups who envisioned urban space in Buenos Aires documented their thoughts. Shantytown residents, for example, did not tend to do so. Hence, some utopian visions are encountered in sources other than the writings of those who conceived them. The article therefore utilises a broad range of historical evidence including shantytown organisations' pamphlets and periodicals; newspapers and magazine articles from a broad range of editorial and political perspectives; Municipal, Provincial, and National legislation; reports produced by State departments which intervened in shantytowns; aerial photos; housing plans; contemporary maps; and oral histories such as those compiled by the Instituto Histórico de la Ciudad de Buenos Aires. Geographically, the visions analysed refer to Greater Buenos Aires, that is, the Capital City and the surrounding districts.

The study of urban informality is attracting renewed interest at the global level as well as in studies about Buenos Aires (Auyero, 2001; Cravino, 2008; Di Virgilio, 2014). The history of Buenos Aires shantytowns, however, has not yet been analysed in depth within existing scholarship. Important exceptions are Eva Camelli's and Valeria Snitcofsky's recent PhD theses (Camelli, 2013; Snitcofsky, 2015). The present article thus makes a twofold contribution: it offers a historiographical account of significant urban practices which are yet to receive scholarly attention; and it inserts Buenos Aires into English-language discussions of Latin American shantytowns. In the article's first section, I introduce the emergence of shantytowns as an urban reality and briefly discuss their initial conceptualisation. In the second, third and fourth sections I discuss different examples of the three utopian visions previously outlined. Finally, I comment on the significance of these utopian visions and their intersections in the modern cityscape. 


\section{The Emergence of Buenos Aires Shantytowns and the Idea of Villa Miseria}

Argentina underwent a significant industrial expansion from the mid-1930s to the mid-1950s, when more than two million people migrated from rural areas to mid-size and large cities in search of better employment opportunities (Germani, 1959: 11; Rock, 1987: 235-248). Before 1929, Argentina had sustained an economic model based on the export of agricultural products and the import of manufactured goods. The drop in international prices that followed the 1929 depression led to a dramatic decline in the country's import capacity and paved the way for industrialisation by means of import substitution. Industrial growth, combined with the decline of employment opportunities in the countryside, led to a substantial shift of labour from the primary (agriculture) to the secondary (industry) and tertiary (services) sectors. After 1945, industrial growth stabilised, and between 1945 and 1955 the state promoted the basic consumer goods industry and the social redistribution of its profits. Later, between 1955 and the late 1970s, the focus of the industrialisation model employed was shifted to intermediate and durable consumer goods and the economy was opened to foreign investment in the hope of deepening industrial development. It is generally held that by the late 1970s Argentina's process of industrialisation took a radical downturn due to the implementation of a neo-liberal economic model (Torrado, 1994: 397-430; de Riz and Torre, 1991: 64-104 and 171).

The shift from agriculture to industry and services after 1929 led to increasing migrations to large Argentine cities, especially to Greater Buenos Aires (Gutman and Hardoy, 2007). Simultaneously, international immigration was dramatically reduced. Thus, in a significant shift from previous periods, migrations to urban centres became mainly national in scope. The population of Greater Buenos Aires increased steadily throughout the period of industrialisation from circa 2,035,000 in 1914 , to $6,600,323$ in 1960. The proportion of internal migrants within Greater Buenos Aires also grew accordingly from 8 percent in 1895, to circa 36 percent in 1957 (Germani, 1959; Dirección Nacional del Servicio Estadístico, 1947: 1 and 32-43, Dirección Nacional de Estadística y Censos, 1960: 2).

The migrants who arrived in Buenos Aires found a city with a long-standing housing shortage and therefore encountered serious problems finding affordable accommodation. Historically, migrants had found lodgings in the tenements known as conventillos or pensiones. However, the deepening of the housing shortage meant that those with the lowest incomes had to turn to accommodation where rent could be spared. The occupation of undeveloped land thus became a viable option and some internal migrants and native city-dwellers, such as newly married couples, started building shacks in large, empty plots in locations relatively close to their workplaces. In most cases, such land had been left undeveloped due to extremely poor conditions for the provision of urban infrastructure (Comisión Nacional de la Vivienda, 1956: 37-40; Ziccardi, 1977: 19-25; Clarín, 1962a). 
Although each shantytown's environmental and social conditions were specific, it is possible to find some commonalities in their development patterns. One of these was the pressing need for basic services such as sewage, electricity, gas, and especially fresh water. Most shantytowns survived with just a few public taps to supply running water for hundreds of families (Nuestra Palabra, 1958; La Hora, 1958d). Additionally, many shantytowns suffered frequent flooding. Some were built on permanent marshlands, others were prone to river floods, and in others rainwater simply took days to drain. Needless to say, in their earlier years, shantytowns lacked paved streets and lighting, refuse collection services, and facilities such as schools and local health centres or dispensaries. Moreover, housing construction was precarious, generally utilising scrap or extremely cheap materials (La Nación, 1947; La Prensa, 1956; Márquez, 1958; La Hora, 1958c; Cronista Mayor de Buenos Aires, 2000, 2002a and 2002b).

Due to their sudden, rapid expansion in the 1940s, Buenos Aires shantytowns were not immediately conceptualised as a specific urban phenomenon. In the context of abundant urban employment and expanded state-sponsored housing schemes, they were considered temporary solutions and it was assumed that their residents would move out relatively quickly (Auyero, 2001: 52-53). The 1955 coup d'état, however, dramatically changed the country's social, political, and economic conditions and greatly affected the shantytowns. First, workers' bargaining power was severely limited, and real wages declined (de Riz and Torre, 1991: 96-139; Torrado, 1994: 410). Second, most statesponsored housing solutions were withdrawn. Third, and crucially, the military government that took power viewed the shantytowns as a reflection of the overthrown administration, and set out to demolish them. Thus, for the first time, the villas miseria ((Argentine shantytowns); literally 'misery villages') not only became a target of government action, but also emerged as a specific urban question in the collective imagination (Camelli and Snitcofsky, 2013; Liernur, 2009).

\section{Upgraded Shantytowns}

Mid-twentieth century shantytowns in Buenos Aires grew by the accretion of individual self-built houses over an extended period of time. Even though they knew few neighbours beforehand, shantytown families soon started gathering together around leisure activities - typically football - and established groups to resolve their most urgent problems. For example, issues related to childcare were dealt with collectively in mothers' clubs. In addition, ad-hoc commissions raised funds and provided labour for filling-up land, extending water and drainage systems, building nurseries and dispensaries, and even paving internal streets (Ziccardi, 1977: 80-91). As two residents of Villa 1-11-14 explained: 
People were always doing things (...) my husband was president of the water commission (...) First they collected the money to buy the pipework (...) people agreed on a date, a Saturday or a Sunday, to work (...) someone more or less familiarised with plumbing would just do it then (...) then all the neighbours who were signed up for this area would help each other to work, and this is how we brought piped water. (Residents Licandra and Beba respectively, quoted in Cronista Mayor de Buenos Aires, 2002a: 05)

Other examples abound. In Villa Inta, throughout the 1950s and 1960s, inhabitants connected their homes to the water pipeworks and electricity networks, and built a chapel, a dispensary and a nursery (Cronista Mayor de Buenos Aires, 2000: 02). In Villa Mariano Acosta, residents extended piped water networks, levelled and paved streets and built a dispensary (La voz de las villas, 1965: 8). In Barrio Lacarra residents constructed a school and a dispensary, paved the corridors, and installed street lights (La voz de las villas, 1970: 1). In Villa Mitre they built public toilets (La Hora, 1959); while in Villa Cildáñez a stable improvements' committee constructed its own premises (La Hora, 1958c). In Villa Jardín, '[p]rocuring drinking water, building their dwellings, filling the lagoons, constructing precarious bridges to cross the small lagoons: everything is said to have been made possible through the active cooperation of neighbours, friends, and relatives' (Auyero, 2001: 54).

Some of these efforts were self-funded. For example, in Villa 20, the residents' commission raised the funds necessary for the nursery and the football pitch through dance parties (Cronista Mayor de Buenos Aires, 2002b, p. 03). In Retiro, adjacent shantytowns worked together to install further public water taps and to build a dispensary, which they funded through football matches (Nuestra Palabra, 1964; La voz de las villas, 1965: 8). In most cases, however, construction efforts had to be combined with negotiations to receive materials, machinery, technical help, or even official permits, from local and/or national governments. This was the case, for example, with the construction of the school Bandera Argentina in Retiro (Comisión Intervillas - Zona Retiro, 1964; La voz de las villas, 1965: 3) and for the extensions of water pipework in Villas Rotonda Varela, 9 de Julio, and General Belgrano (La voz de las villas, 1965: 6-7) (Figure 1). As shown in various sources, shantytown committees were constantly requesting support from state bodies like local councils and offering their free labour (Nuestra Palabra, 1963; La voz de las villas, 1965: 1; Lucha vecinal, c.1965). Facilities that required staff, such as schools, dispensaries, and nurseries, usually relied on residents' unpaid labour supported by paid municipal staff and/or volunteer professionals.

Which visions inspired these efforts? The villa residents' priorities, funding mechanisms, and implementation practices suggest an answer: residents envisioned an upgraded neighbourhood in the short term, stemming from their own efforts. Additionally, written sources produced by at least some residents offer a more detailed account of their perspectives (Lucha vecinal, c.1965). In these, the vision 
of an upgraded shantytown in the short term is combined with the vision of a state housing plan for the longer term. A city-wide shantytown organisation, the Federación de Villas y Barrios de Emergencia (Shantytowns and Emergency Neighbourhoods Federation), also sustained this view (La voz de las villas, 1965, 1969 and 1970). In other words, until the late 1960s the residents considered the villas temporary accommodation to be upgraded only until further dwelling solutions were provided by the state (Auyero, 2001). In the written accounts, inhabitants' expressions of their own visions were often accompanied by a critique of the larger social structure, citing such problems as poverty, working conditions, state neglect or repression.

Gradually through the 1960s shantytown residents realised that the state would not facilitate any housing scheme that could solve their accommodation problem. This became painfully evident when the 1968 eradication plan (which will be discussed further below) not only harassed and evicted residents, but completely failed to fulfil its housing promises (La voz de las villas, 1969). Thus, by the early 1970s residents had adopted the utopian vision of a fully upgraded and self-built neighbourhood exclusively and they expected state support in setting up their own shantytown construction enterprises. This is reflected in the claims advanced by a later shantytown organisation, the Movimiento Villero Peronista (Peronist Shantytowns Movement) (El descamisado, 1973).

Earlier, I defined utopian visions as collective conceptions that entail a socio-political critique of a present state translated into space which points towards an ideal future. It could be argued that neighbourhood initiatives like those discussed above only represented scattered attempts to address the most immediate concerns emerging from the shantytown environments. However, such initiatives were driven by a specific spatial vision. The space envisioned implied a social order in which everyone had the right to reside in the city, and focused on low-budget, short-term solutions to achieve this aim. In other words, the legitimacy of staying on invaded land and upgrading it reflected an imaginary where land was meant to be used, and this practical necessity was more important than ownership. These were, therefore, utopian visions which can be read in the everyday actions of ordinary people.

A literary formulation of the utopian vision of fully upgraded-shantytowns can be found in Bernardo Verbitsky's novel Villa Miseria también es América (1957), which describes how a group of migrants gathered together in a villa to improve their dwelling standards and environment. Villa Miseria... was the first literary text to formulate a specific discourse to describe the shantytowns, and it presented them as the living place of hard-working, well-deserving families and individuals, and as a site for the development of solidarity networks:

By working, they created the future in the present, and enjoyed the pleasure of this effort. At least, that was how he felt about it. Some considered the whole effort pointless. Why 
struggle so much? In the best case scenario it was to be owners of that rubbish dump. But to work is to prove oneself, to fight for something; it is, at least, to breathe deeply [...]. Sometimes the terrifying thing in that place was the intuition that there was no future. (Verbitsky, 1957: 14)

The popularity of Verbitsky's novel, which won the Buenos Aires Municipal Prize in 1957, suggests that his ideas resonated with a substantial proportion of the public (Gorelik, 2009: 80). Indeed, the utopian vision of a city with fully-upgraded shantytowns was formulated and sustained not only by residents but also by various social groups. Certain political parties, such as the Communist Party, supported the vision of upgraded shantytowns (Blaustein, 2001; Communist newspapers Nuestra Palabra and La Hora). Moreover, Socialist deputy Juan Carlos Coral presented legal bills proposing shantytown improvements (Coral, 1965). In certain cases state departments even supported the residents' efforts to upgrade existing shantytowns. In Villa Jardín, for example, a school was opened by the National government in 1954 (Auyero, 2001: 55). Residents of Villa 20 also refer to government-aided improvements (Cronista Mayor de Buenos Aires, 2002b: 02). During the late 1950s and early 1960s, in addition, the city councils of Buenos Aires and Lanús provided construction materials for shantytown commissions to complete upgrades (La Hora, 1958a and 1958b; Resoluciones Municipales 14.447, $1958 ; 15.694,1959 ; 16.597,1960 ; 17.231,1961$; and 17.497, 1961). Finally, the utopian vision of upgraded shantytowns gained popularity among architects and planners in response to John Turner's ideas emphasising the importance of citizen' participation in housing production (Turner, 1976).

Importantly, state support for upgrades was largely supplied by local governments and promoted by City Councils. The districts of Lanús, La Matanza and the Capital City were notably active in this regard, and in them councillors from the Unión Cívica Radical Intransigente and Communist Party played a important role in promoting these efforts. Additionally, the government of Arturo Illia (19631966) received residents' demands for state-aided improvements and housing positively. However, it did not offer material support. While shantytown residents sustained the utopian vision of fully-serviced shantytowns throughout the second half of the twentieth century, it was only in periods of democracy that it was shared by some state actors.

\section{State-Supported Universal Housing}

The rapid expansion of shantytowns in Buenos Aires gave fresh impetus to public discussions about affordable housing which had first emerged in the late nineteenth century. Until the mid-1930s, in the context of liberal economic ideology, housing initiatives were primarily promoted by civil groups. From 
this point on, calls for state intervention grew, although a very limited portion of the state budget was allocated to housing. After 1943, with Juan Domingo Perón as Secretary of Labour, official discourse started to recognise housing as a fundamental component of workers' rights to wellbeing that should be safeguarded by the state (Ministerio de Relaciones Exteriores y Culto, 1940: 28-29; Constitución de la Nación Argentina, 1949: 28-29). Once he assumed the presidency, Perón's administration (1945-1955) attempted to realise this vision through two main policies: it built complexes of social housing and it expanded the mortgage schemes offered by the National Mortgage Bank (Aboy, 2005; Ballent, 2005 : 63-96) (Figure 2). These were accompanied by Perón's general project of inclusionary citizenship whereby public urban spaces were offered to the working classes for the first time (Podalsky, 2004). After 1955, the state gradually retreated from the vision of state-sponsored universal housing, eventually abandoning it altogether. Nonetheless, it retained a central place within the collective imaginary.

The vision of a city able to accommodate everyone by means of social housing was also a collective construction. It had been formulated by multiple civil groups, legislators, and public figures during the 1920s and 1930s before being implemented by Perón. The working classes enthusiastically embraced this vision. As previously discussed, shantytown residents originally combined the utopian vision of an upgraded villa with that of a universal housing plan. The vision was also celebrated by the printed media, by wider sections of the general public (Nuestra Palabra, 1961; Clarín, 1962b), and particularly by architects, as it combined the ideal of an inclusive society with material interventions in the built environment. For architects, this vision presented an exciting design challenge, increased employment opportunities, and also the chance to incorporate social responsibility into their practice. Such enthusiasm is evident in the ways in which architects interpreted state plans to evict shantytowns. In fact, many plans combined villas eviction with proposals of re-accommodation of residents into statebuilt housing. Although eviction was the main aim for these plans, architects read them as housing schemes and were later disappointed (Erradicación de villas de emergencia, 1969; Summa, issues 9 (1967), 10 (1967) and 36 (1971)).

Importantly, after being overthrown by the 1955 coup d'état, the Peronist party was proscribed until 1973. As such party would otherwise have held a majority, the governments elected in those years suffered from a lack of legitimacy (de Riz and Torre, 1991). Thus, when these governments (or fractions of them) sustained the vision of universal housing, they lacked sufficient political power to implement it as had Perón's administration from 1945-1955. In 1973 the Peronists won a new round of elections, but were ousted again in 1976 by the most violent dictatorship in Argentine history.

Insofar as the vision of universal state-sponsored housing contains a critique of the existing city unable to provide full accommodation, it is utopian within the framework I have described. Moreover, it translates the vision of an inclusive society in spatial terms through the provision of housing. Unlike paternalist positions where housing is facilitated as a favour, or those positions which demanded that 
workers earned their accommodation through their own virtues (hard work, discipline, austerity), this vision is underpinned by the assumption that housing is a basic right. While the vision of universal housing does not necessarily exclude citizens' input (state support can be facilitated, for example, through loans that families use to self-build) it is distinguished from other conceptions by its universal nature and the fact that it works within the existing legal framework (while shantytown upgrade, as the land is invaded, does not).

\section{Shantytown Eviction}

Thus far, this article has analysed two utopian visions that emerged following the establishment of shantytowns in Buenos Aires and has argued that they were shared by different groups within Argentine society. These visions, upgraded shantytowns and universal state-sponsored housing, focused on the provision of dwelling solutions. However, other groups within society advocated forced eviction (sometimes accompanied by the allocation of alternative housing) as a means to make the shantytowns disappear. For example, the military government who took power in 1955 created the Plan de Emergencia (PE; Emergency Plan; 1956), the first state plan for shantytown eradication. Convinced that the shantytowns were a reflection of the demagoguery and ineffective housing policies of Perón's overthrown government, and that internal migration and land occupation were the unwanted effects of an administration which had given workers too much, the 1955-1958 military government embodied its views in this plan. For example, the PE viewed the villas miseria as 'permanent foci of epidemics and moral degradation' (Comisión Nacional de la Vivienda, 1956: 39). In this instance, 'morality' is understood as industriousness, respect for the law and private property, and an urban lifestyle based upon married couples living with their children. The internal migrants, however, were not necessarily married when co-habiting and used to host relatives and friends as they arrived from the provinces. Thus, the PE proposed to re-accommodate shantytown residents into purpose-built housing complexes designed as 'adaptation dwellings' which assigned a fixed use to each room in the residences in an attempt to coerce the inhabitants to live in nuclear families of five to ten people, and thus assimilate them into society (Comisión Nacional de la Vivienda, 1956: 151-153; Massidda, 2012). Hence, even though the PE intertwined the utopian visions of villas clearance and housing provision, it was largely articulated around the idea of making the shantytowns invisible. This invisibility was to be achieved by the twofold movement of physically destroying them plus assimilating their inhabitants.

The PE was the first in a series of state plans that sought to construct a city without shantytowns. During 1958-1962 certain unimplemented laws embodied this vision (Resolución Municipal 14.449,1958; Decreto Municipal 15.759, 1962), and in 1966 the Municipality launched the Plan Piloto de Erradicación de Villas de Emergencia (Shantytown Eradication Pilot Plan) to this aim. As a 
municipal plan, the Plan Piloto applied only to the Capital City and not to the surrounding districts. The Plan Piloto was part of the larger modern urban development initiative Parque Almirante Brown (PAB; Admiral Brown Park), partially funded by the Alliance for Progress (Comisión Municipal de la Vivienda, 1965). Within the context of the Cold War, and due to US concerns about the influence of the Cuban Revolution, modern urban development was seen, by both the United States and Inter-American organisations, as a route to social betterment which would maintain the existing economic structure and undermine the appeal of Communism (Gorelik, 2014). Slum clearance was an essential element of these plans (Unión Panamericana, 1958). Thus, even though local, the views of the Plan Piloto were framed by an international discussion taking place in the Americas.

In the Plan Piloto, shantytowns were portrayed as an obstacle blocking the creation of a modernised, forward-looking city. Like the PE, this initiative contained an element of social engineering. This was to be achieved, however, through an alternative mechanism. In this instance, the municipal housing commission appointed social workers to 'chang[e] the mental attitude of the shantytowns' inhabitants, which is characterised by their static laziness, and transforming this attitude into a dynamic process of order, organisation and development' (Comisión Municipal de la Vivienda, 1966). In practice, this meant convincing residents to accept moving and to embrace the discourse which underpinned the Plan. In this way, the Plan Piloto implemented some shantytown improvements with the intention of gaining people's good will and minimising their resistance. Parallel to this, it replaced shantytown committee members with residents who supported the plan, or with municipal employees. In other words, the utopian vision sustained by the Plan Piloto was that of shantytown clearance, although it temporarily professed to sustain a vision of upgrade. Ultimately, the Plan's purpose was to de-activate the committees as engines of improvement and resistance to eviction, and transform them into tools of indoctrination (Comisión Municipal de la Vivienda, 1966: IV; Ziccardi, 1977: 127-135; Blaustein, 2001: 23 and 33).

In 1968 the Plan Piloto was absorbed into the Plan de Erradicación de Villas de Emergencia (PEVE; Shantytown Eradication Plan), a national plan implemented by local departments. Much like its precursors, the PEVE advocated a civilising mission in conjunction with the promotion of spatial order, and it advanced a more extreme version of the 'adaptation dwellings' previously promoted by the PE. Evicted families were first re-housed in minimal, precarious, units which according to the PEVE would force residents to desire an improvement in their housing situation. Thereafter, residents were supposed to be offered permanent flats (Ministerio de Bienestar Social, 1968; Yujnovsky, 1984: 123-169). However, few permanent housing complexes were actually built, and the temporary units became permanent homes for most evicted families. Moreover, those permanent complexes which were built were largely unaffordable for former shantytown residents. While some accepted the relocation plans regardless, most resisted the process as they understood that the eviction plans embodied the vision of a 
city without villas miseria, but equally without universal housing (La voz de las villas, 1969 and 1970). After 1973, the PEVE was re-launched as the Plan Alborada.

The utopian vision of shantytown clearance is based on force and repression. It does not address the roots of the problem (poverty and the scarcity of affordable urban housing), nor does it offer substantial solutions. Rather, it aims to achieve its spatial ideals through compulsory exclusion and the imposition of a particular lifestyle. For example, the Plan Piloto did not promote genuine upward social mobility, but viewed social progress as the imposition of acceptable cultural standards. In addition, the denomination plans of 'eradication' itself - a term normally used to refer to epidemics, weeds or diseases -indicates that such plans went beyond the spatial removal of the villas and sought a rather more radical erasure of one group of society. Ultimately, the vision of a city with shantytowns forcibly removed called for the elimination of Otherness, be it by the physical removal of those who are considered different, or by their assimilation.

As previously discussed, the 'eradication' plans guided by a utopian vision of evicted shantytowns often appeared to include the provision of housing. However, they were not inspired by the vision of universal housing, but rather included the provision of the minimum number of housing units necessary to facilitate the effective implementation of the plans. Nonetheless, these state plans were implemented by numerous individuals who held slightly different positions. In addition to architects, who designed the eviction plans while sustaining the vision of universal housing, some public servants were more interested in housing provision than others (Dávolos, Jabbaz, and Molina, 1987). While the plans were designed to focus on eviction, in practice they were re-imagined in different ways by the different individuals who implemented them. Arguably, the most extreme manifestation of the utopian vision of evicted-shantytowns was the series of bulldozer operations put into practice by the City of Buenos Aires during the last Argentine dictatorship (Figure 3). As Guillermo del Cioppo, director of the municipal housing commission (1976-1982), declared, 'living in Buenos Aires is not for everybody but for those who deserve it' (del Cioppo, 1980 cited Oszlak, 1991: 78). In the midst of an (in)famous wave of kidnappings and torture, several shantytowns were demolished and residents forcibly removed. As no alternative accommodation was offered, this utopian formulation did not include any housing promise whatsoever. Osvaldo Cacciatore, the mayor (1976-82), proudly declared, 'we have evicted 145,000 people without spending one single peso' (Cacciatore, 1980 cited Cronista Mayor de Buenos Aires, 2000: 09). The evicted residents were transported from the Capital City to the surrounding districts by the Municipality, leaving them to their own devices (Blaustein, 2001).

The eradication procedures adopted by the Municipality of Buenos Aires were framed within by the views of a dictatorship which sustained an exclusionary perspective towards city and society; which attempted to impose a neoliberal model on the economy; and which, in order to institute these projects, attempted to exterminate anyone considered to be subversive. With the possible exception of the 
massacres of Indians during the Spanish Conquest and the nineteenth-century Campaña del Desierto (Rock, 1987: 367-373), this genocide was unprecedented. Furthermore, it must be noted that members of the same dictatorship which attempted to bulldoze all shantytowns in 1980 had already persecuted and ravaged the Movimiento Villero Peronista during the period 1974-1978. Unlike the previous eviction plans, which sought to forcibly 're-educate' and assimilate shantytown residents, these plans simply sought to annihilate them. Social and spatial exclusion are thus intertwined, and co-function, within these models. While it may appear that it was mainly dictatorships which sustained the vision of evicted shantytowns, as it was the de facto governments who implemented these plans, a deeper look at legislation, official documents, and newspapers articles, shows that this vision was present throughout the 1960s, albeit in a less explicit manner. Indeed, although it is now viewed as politically incorrect, it is still largely present in Argentine society (Massidda, 2012).

Interestingly, the last dictatorship's extreme version of the evicted-shantytowns vision led to a renewed interest in, and application of, the upgraded-shantytowns vision. Evicted families resorted, among other popular strategies, to collective squatter settlements which ultimately embodied the upgrade ideal. These settlements consisted of land squats conceived from the outset as permanent neighbourhoods. Thus, existing street patterns were followed in order to be recognised as part of the regular urban fabric, and more easily to receive services through council support. Thus, a pure manifestation of the evicted-shantytowns ideal led to a re-imagined practice of full upgrading, which is extensive in popular housing initiatives today (Cravino, 2008).

\section{Conclusion: Utopías Villeras}

The different utopian visions analysed in this article are not limited to a specific set of practices, nor are they necessarily linked to a specific political position. Rather, they are found in multiple formulations, and are frequently intertwined. From a diachronic perspective, I have explored how the visions of upgraded villas, universal housing, and demolished shantytowns were expressed and realised throughout Argentine history. In some instances, the vision of universal housing accompanied that of upgraded shantytowns in such a way that both retained a vital role. In others, it appeared to be linked to the evicted-shantytowns ideal, but clearly in a subordinate role, or was sustained only by certain individuals. Nonetheless, at certain points these visions have been expressed in a singular manner, as was the case with the housing policies of 1940s Peronism, in the last dictatorship's eradication practices, or in post1970s squatter settlements.

From a synchronic perspective, all three utopian visions have continued to be expressed in recent years. Shantytown upgrade and state-sponsored housing provision are central issues within contemporary Argentine debates concerning social inclusion and urbanisation policy, as evidenced by 
frequent discussion in the newspapers Página 12, Clarín, and the shantytown publication Mundo Villa. This enthusiasm is echoed by an increasing interest at the professional level in disciplines such as architecture, law, economy, sociology and anthropology. At the state level, legislation and programmes are actively seeking to upgrade and title shantytowns (Bontempo, 2010: 202-203), while a statesponsored cultural centre recently opened in Villa 21 (Casa Central de la Cultura Popular, 2015). In addition, the utopian vision of universal housing is reflected in such state programmes as ProCreAr, the Plan Federal, or specific arrangements with local governments (Bontempo, 2010). Architects have likewise maintained their interest in this ideal (Programa de Mantenimiento Habitacional, 2000; Revista de Arquitectura, 2009). The evicted-shantytowns vision, however, does not appear as often in public discussion, although it does underlie the thinking of wide sectors of society (Massidda, 2012).

Despite these extensive efforts and debates, no shantytown has yet been fully urbanised, and living conditions within them continue to be extremely difficult. As shantytowns continue to represent the main area of urban growth in contemporary Buenos Aires (Cravino, 2008), however, these debates are ever more pressing. By examining the urban through utopian visions, one can distinguish close-knit discourses and practices, and re-formulate critiques of the present. Ultimately, exploring the ways in which different visions crystallised into different forms of urban intervention in the past allows us to reformulate our own future imaginaries for present-day Latin-America.

\section{References}

Aboy, R. (2005) Viviendas para el pueblo: espacio urbano y sociabilidad en el barrio Los Perales. 1946-1955. Fondo de Cultura Económica: Buenos Aires.

Auyero, J. (2001) Poor People's Politics: Peronist Survival Networks and the Legacy of Evita. Duke University Press: Durham.

Ballent, A. (2005) Las huellas de la política: vivienda, ciudad, peronismo en Buenos Aires, 1943-1955. Universidad Nacional de Quilmes/Prometeo: Buenos Aires.

Bayat, A. (2013) Life as Politics: How Ordinary People Change the Middle East. Stanford University Press: Stanford.

Blaustein, E. (2001) Prohibido vivir aquí: una historia de los planes de erradicación de villas de la última dictadura. Comisión Municipal de la Vivienda: Buenos Aires.

Bontempo, L. (2010) Umbrales de un siglo. Una historia de la vivienda social en la Argentina. De los conventillos al Plan Federal. Ministerio de Planificación Federal, Inversión Pública y Servicios: Buenos Aires.

Camelli, E. (2013) Politicidad villera. El Movimiento Villero Peronista, 1973- 1976. Unpublished doctoral dissertation, Universidad de Buenos Aires, Buenos Aires. 
Camelli, E. \& Snitcofsky, V. (2013) 'La 'villa' de Buenos Aires: Génesis, construcciones y sentidos de un término', Café de las ciudades, 11(122-123), December 2012-January 2013. [WWW document]. URL http://www.cafedelasciudades.com.ar/cultura_122.htm [accessed 1 April 2016].

Casa Central de la Cultura Popular (2015) [WWW document]. URL http://www.cultura.gob.ar/museos/casa-de-la-cultura-villa-21-barracas/ [accessed 21 October 2015].

Cravino, M. C. (ed.) (2008) Los mil barrios (in)formales: aportes para la construcción de un observatorio del hábitat popular del Área Metropolitana de Buenos Aires. Universidad Nacional de General Sarmiento: Los Polvorines.

Comisión Municipal de la Vivienda (1965) Centro Urbano Integrado Parque Almirante Brown: solicitud de préstamo al Banco Interamericano de Desarrollo. Municipalidad de la Ciudad de Buenos Aires, Buenos Aires.

Comisión Municipal de la Vivienda (1966), Plan Piloto para Erradicación de Villas de Emergencia: Villas de emergencia $n^{\circ}$ 5-6-18. Municipalidad de la Ciudad de Buenos Aires, Buenos Aires.

Comisión Nacional de la Vivienda (1956), Plan de Emergencia: Informe elevado al Poder Ejecutivo Nacional. Ministerio de Trabajo y Previsión, Buenos Aires.

Constitución de la Nación Argentina (1949). Congreso de la Nación, Buenos Aires.

Coral, J. C. (1965) En defensa de las familias obreras que habitan las villas de emergencia: proyectos presentados ante la Cámara de Diputados por el diputado socialista argentino Juan Carlos Coral. Buenos Aires.

Dávolos, P., Jabbaz, M. \& Molina, E. (1987) Movimiento villero y estado (1966-1976). Centro Editor de América Latina: Buenos Aires.

de Riz, L. \& Torre, J. C. (1991) 'Argentina since 1946’. In Bethell, L. (ed.). The Cambridge History of Latin America (Vol. VIII). Cambridge University Press: Cambridge, 73-101.

Decreto Municipal 15.759. Creación de una comisión para la eliminación de tugurios (1962), Boletín Municipal de la Ciudad de Buenos Aires, 11,940, 9 October.

Dirección Nacional de Estadística y Censos (1960) Censo Nacional de Vivienda 1960 (Vol. I). Dirección Nacional de Estadística y Censos.

Dirección Nacional del Servicio Estadístico (1947) IV Censo General de la Nación. Población. 1947 (Vol. I). Dirección Nacional del Servicio Estadístico, Buenos Aires.

Di Virgilio, M. M., Guevara, T. A. \& Arqueros Mejica, M. S. (2014) 'Políticas de regularización en barrios populares de origen informal en Argentina, Brasil y México'. Urbano 17(29): 57-65.

Germani, G. (1959) El proceso de urbanización en la Argentina. Facultad de Filosofía y Letras, Universidad de Buenos Aires: Buenos Aires. 
Gorelik, A. (2009) 'Buenos Aires is (Latin) America, Too'. In Biron, R. (ed.). City/Art: The Urban Scene in Latin America. Durham University Press: London, 61-84.

Gorelik, A. (2014) 'Miradas cruzadas. El viaje latinoamericano del planning norteamericano'. Bifurcaciones (18): 1-20.

Gutman, M., and Hardoy, J. E. (2007) Buenos Aires 1536-2006. Historia urbana del área metropolitana. Infinito: Buenos Aires.

Heffes, G. (2009) Las ciudades imaginarias en la literatura latinoamericana. Beatriz Viterbo: Buenos Aires.

Heffes, G. (2013) 'Introducción'. In Heffes, G. (ed.). Utopías urbanas: geopolíticas del deseo en América Latina. Iberoamericana: Madrid, 13-45.

Hernández, F. (forthcoming) 'The Challenge of Marginality in Latin American Cities'. In Becerra, A. \& Hernández, F. (eds.). Marginal Urbanisms: Informal and Formal Development in Cities of Latin America. Cambridge Scholars Publishing: Newcastle upon Tyne, 3-49.

Holston, J. (2008) Insurgent citizenship: Disjunctions of Democracy and Modernity in Brazil. Princeton University Press, Princeton and Oxford.

Lejeune, J. F. (Ed.) (2005) Cruelty and Utopia: Cities and Landscapes of Latin America. Princeton Architectural Press : New York.

Liernur, J. F. (2009) 'De las "nuevas tolderías" a la ciudad sin hombres: La emergencia de la "villa miseria” en la opinión pública (1955-1962)’. Registros (6): 7-24.

Logan, G. \& Adams, R. (2002) 'Introduction'. In More, T., Utopia. Cambridge University Press: Cambridge, $\mathrm{xi}-\mathrm{xxix}$.

Massidda, A. L. (2012) 'The Plan de Emergencia (1956): Housing Shortage in Buenos Aires Then and Now'. Scroope: The Cambridge Architecture Journal (21): 42-51.

Ministerio de Bienestar Social (1968) Plan de Erradicación de las Villas de Emergencia de la Capital Federal y el Gran Buenos Aires: Primer programa - erradicación y alojamiento transitorio. Buenos Aires.

Ministerio de Relaciones Exteriores y Culto (1940), Primer Congreso Panamericano de la Vivienda Popular: Actas y trabajos (Vols. 1-2). Ministerio de Obras Públicas, Buenos Aires.

More, T. ([1516] 2002) Utopia. Cambridge University Press: Cambridge.

Mumford, E. (1997) 'CIAM and Latin America'. In Sert: Arquitecto en Nueva York. Barcelona: Museu d'Art Contemporani, 48-75.

Oszlak, O. (1991) Merecer la ciudad: los pobres y el derecho al espacio urbano. CEDES/Hvmanitas: Buenos Aires.

Podalsky, L. (2004) Specular City: Transforming Culture, Consumption, and Space in Buenos Aires, 1955-1973. Temple University Press: Philadelphia. 
Programa de Mantenimiento Habitacional (2000) 90 años de vivienda social en la ciudad de Buenos Aires. Universidad de Buenos Aires: Buenos Aires.

Resolución Municipal 14.447 (1958), Boletín Municipal de la Ciudad de Buenos Aires, 10,923, 22 July.

Resolución Municipal 14.449 (1958), Boletín Municipal de la Ciudad de Buenos Aires, 10,916, 22 July.

Resolución Municipal 15.694 (1959), H. Concejo Deliberante (Ciudad de Buenos Aires), 5 November.

Resolución Municipal 16.597 (1960), Boletín Municipal de la Ciudad de Buenos Aires, 11,448, 31 August.

Resolución Municipal 17.231 (1961), Boletín Municipal de la Ciudad de Buenos Aires, 11,543, 06 March.

Resolución Municipal 17.497 (1961), Boletín Municipal de la Ciudad de Buenos Aires, 11,621, 14 June.

Rock, D. (1987) Argentina, 1516-1987: From Spanish Colonization to Alfonsín. Tauris: London.

Salcedo Fidalgo, A. \& Zeiderman, A. (2008) 'Antropología y ciudad: hacia un análisis crítico e histórico'. Antípoda: revista de antropología y arqueología (7): 63-97.

Snitcofsky, V. (2015) Villas de Buenos Aires: historia, experiencia y prácticas reivindicativas de sus habitantes (1958-1983). Unpublished doctoral dissertation, Universidad de Buenos Aires, Buenos Aires.

Torrado, S. (1994) Estructura social de la Argentina, 1945-1983. Ed. de la Flor: Buenos Aires.

Turner, J. F. C. (1976) Housing by People: Towards Autonomy in Building Environments. Marion Boyars: London.

Unión Panamericana (1958) Informe de la Secretaría de Consejo Interamericano Económico y Social sobre la Primera Reunión Técnica Interamericana en Vivienda y Planeamiento. Secretaría General, Organización de los Estados Americanos, Washington D.C..

Verbitsky, B. (1957) Villa Miseria también es América. B G. Kraft: uenos Aires.

Yujnovsky, O. (1984) Claves políticas del problema habitacional argentino (1955-1981). Grupo Editorial Latinoamericano: Buenos Aires.

Ziccardi, A. (1977) Políticas de vivienda y movimientos urbanos: El caso de Buenos Aires (1963-1973). Centro de Estudios Urbanos y Regionales, Instituto Torcuato di Tella: Buenos Aires. 


\section{Newspapers}

Comisión Intervillas - Zona Retiro (1964) 'Escuela 'Bandera Argentina'. Leaflet.

Clarín, 1962a. 'Sólo casas para ricos...'. Clarín, 1 February.

Clarín, 1962b. Comuna: Adjudicará la Construcción de 5.700 Viviendas. Clarín, 4 February.

Cronista Mayor de Buenos Aires, issues 20 (2000), 33 (2002a) and 34 (2002b). Instituto Histórico de la Ciudad de Buenos Aires: Buenos Aires.

El Descamisado, 1973. Villeros peronistas, unidos y organizados hacia la liberación. El Descamisado, 30 Octubre (24), pp. 10-13.

'Erradicación de villas de emergencia' (1969) Revista de Arquitectura (65), 36-39.

La Hora, 1958a. Presentan en Lanús el pedido para mejorar los barrios de emergencia. La Hora, 9 May.

La Hora, 1958b. Entrevistose con el intendente la Comisión de la Vivienda. La Hora, 14 September.

La Hora, 1958c. Villa Lugano, barrio proletario que avanza merced al esfuerzo vecinal: En el barrio Villa Cildáñez. La Hora, 19 October.

La Hora, 1958d. Villas de emergencia, faltas de agua y luz - a pocas cuadras de Plaza Flores. La Hora, 16 November.

La Hora, 1959. Villa Mitre: Un 'pueblo’ al costado de las vías. La Hora, 3 January.

La Prensa, 1956. Miles de personas se alojan en casas miserables. La Prensa, 19 March.

La Nación, 1947. Las obras de urbanización en los bañados de Flores. La Nación, 21 January, p. 6.

La voz de las villas, issues (1965, February), (1969, August) and (1970, April). Federación de Villas y Barrios de Emergencia: Buenos Aires.

Lucha Vecinal: Boletín de las villas de Retiro (c. 1965).

Márquez, L., 1958. Así viven 50.000 personas. Nuestra Palabra, 5 June.

Nuestra Palabra, 1958. Villa Jardín: donde el mate se toma con soda. Nuestra Palabra, 24 April.

Nuestra Palabra, 1961. La vivienda, un derecho efectivo. Nuestra Palabra, 25 July.

Nuestra Palabra, 1963. Las 'villas miserias' pasan a la ofensiva: puntos del memorial presentado a Illia. Nuestra Palabra, 20 August.

Nuestra Palabra, 1964. Villa Comunicaciones, ejemplo a imitar y mejorar. Nuestra Palabra, 3 November.

Revista de arquitectura (2009)

Summa, Issues 10 (1967, December) and 18 (1969, September). 


\section{Figs}

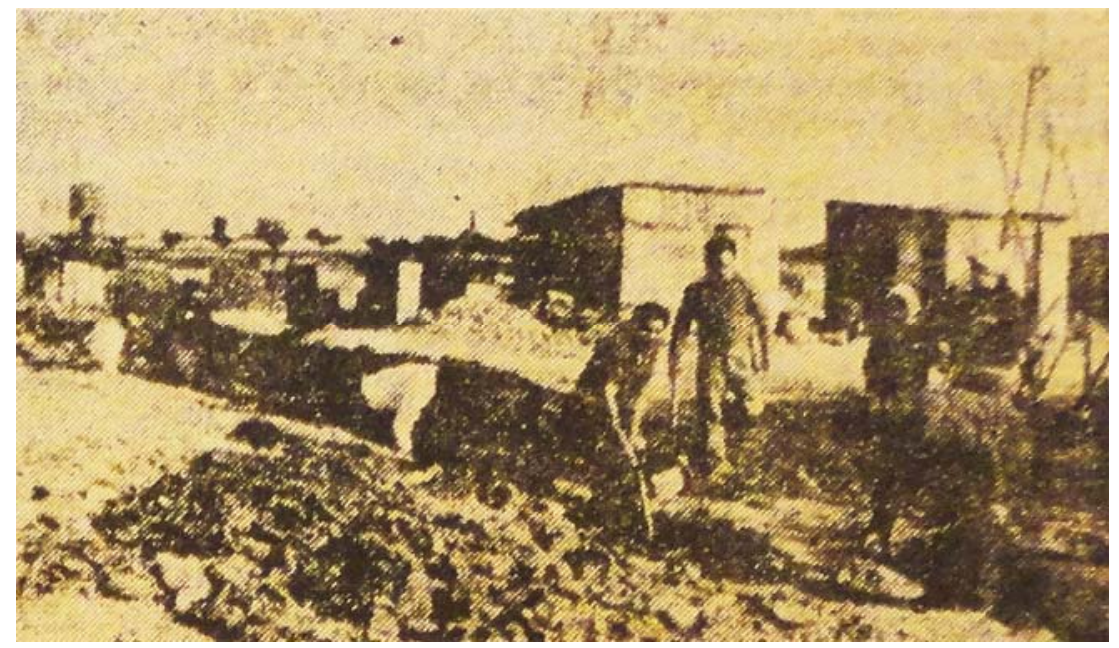

Figure 1. Residents of Villa Rotonda Varela opening trenches for fresh water pipework. Source: La voz de las villas, February 1965.

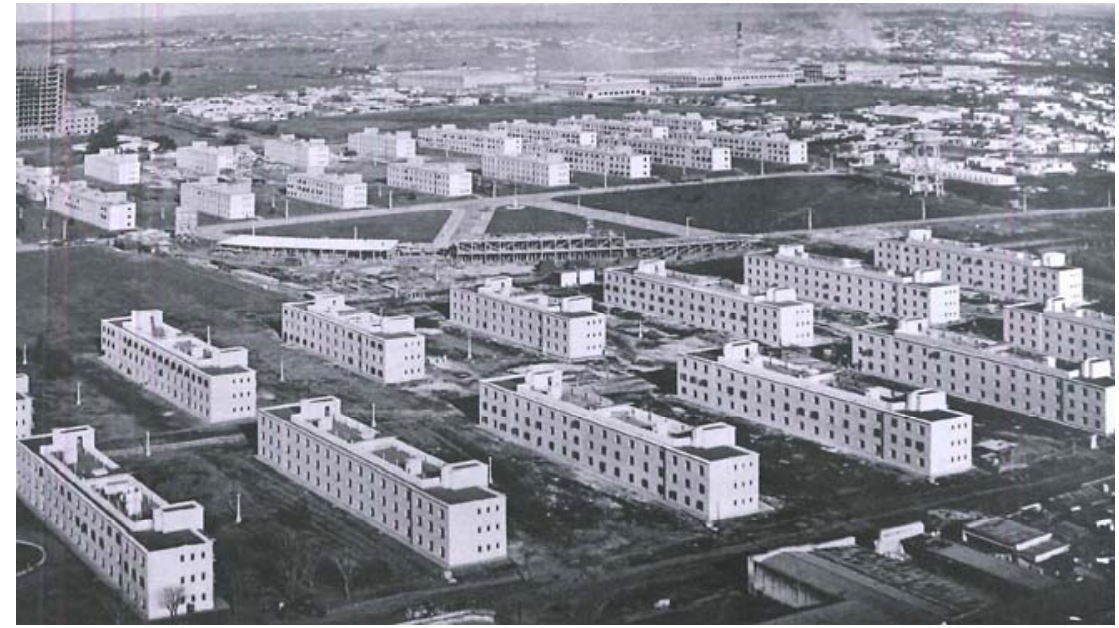

Figure 2. Los Perales housing complex, City of Buenos Aires, opened 1949. Source: Archivo General de la Nación.

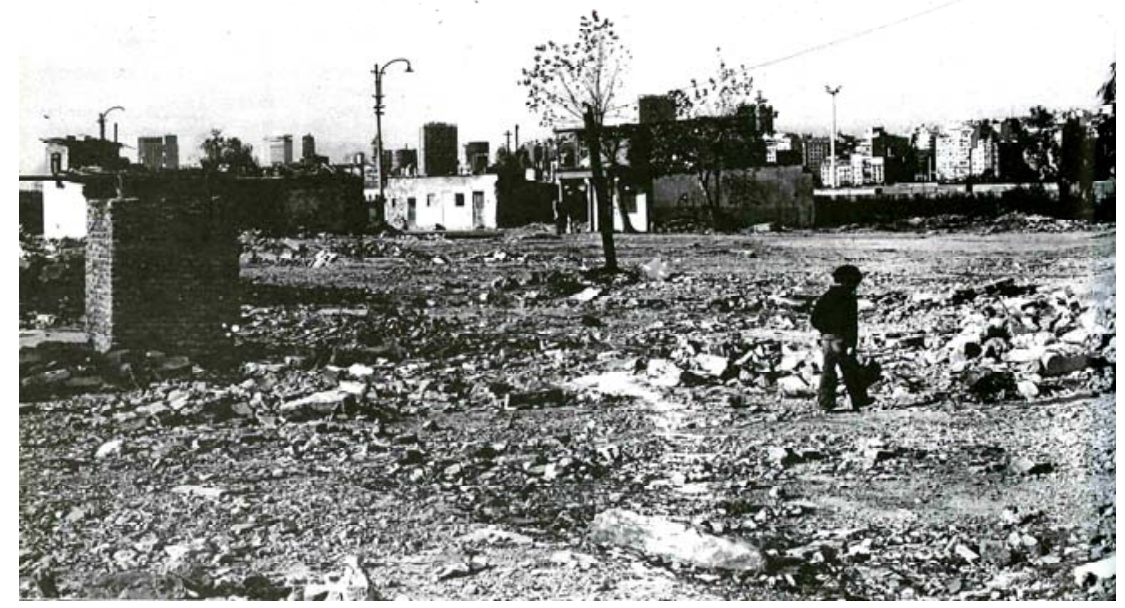

Figure 3. Shantytown 'eradications' circa 1977. Source: Eduardo Blaustein, Prohibido vivir aquí: Una historia de los planes de erradicación de villas de la última dictadura (Buenos Aires: Comisión Municipal de la Vivienda. 2001). 